\title{
Infection patterns of endemic human coronaviruses in rural
}

\section{households in coastal Kenya [version 1; peer review: 1}

\section{approved]}

\author{
Dickson Machira Nyaguthii (D1,2*, Grieven P. Otieno (D)1*, Ivy K. Kombe (D1, \\ Dorothy Koech1', Martin Mutunga1', Graham F. Medley (i)3, D. James Nokes (D)1,4, \\ Patrick K. Munywoki (iD)
}

\footnotetext{
${ }^{1}$ Epidemiology and Demography department, KEMRI-Wellcome Trust Research Programme, Kilifi, 80108, Kenya ${ }^{2}$ Department of Veterinary Public Health, Pharmacology and Toxicology, Egerton University, Egerton, Kenya ${ }^{3}$ Centre for Mathematical Modelling of Infectious Disease, London School of Hygiene and Tropical Medicine, London, UK ${ }^{4}$ School of Life Sciences and Zeeman Institute for Systems Biology and Infectious Disease Epidemiology Research (SBIDER), University of Warwick, Coventry, UK

* Equal contributors
}

V1 First published: 09 Feb 2021, 6:27

https://doi.org/10.12688/wellcomeopenres.16508.1

Latest published: 09 Feb 2021, 6:27

https://doi.org/10.12688/wellcomeopenres.16508.1

\section{Abstract}

Background: The natural history and transmission patterns of endemic human coronaviruses are of increased interest following the emergence of severe acute respiratory syndrome coronavirus-2 (SARS-CoV-2).

Methods: In rural Kenya 483 individuals from 47 households were followed for six months (2009-10) with nasopharyngeal swabs collected twice weekly regardless of symptoms. A total of 16,918 swabs were tested for human coronavirus (hCoV) OC43, NL63 and $229 \mathrm{E}$ and other respiratory viruses using polymerase chain reaction. Results: From 346 (71.6\%) household members, 629 hCoV infection episodes were defined, with $36.3 \%$ being symptomatic: varying by hCoV type and decreasing with age. Symptomatic episodes (aHR=0.6 (95\% CI:0.5-0.8) or those with elevated peak viral load (medium aHR=0.4 (0.3-0.6); high aHR=0.31 (0.2-0.4)) had longer viral shedding compared to their respective counterparts. Homologous reinfections were observed in 99 (19.9\%) of 497 first infections. School-age children $(55 \%)$ were the most common index cases with those having medium $(\mathrm{aOR}=5.3(2.3-12.0))$ or high (8.1 (2.9 - 22.5)) peak viral load most often generating secondary cases.

Conclusion: Household coronavirus infection was common, frequently asymptomatic and mostly introduced by school-age children. Secondary transmission was influenced by viral load of index cases. Homologous-type reinfection was common. These data may be insightful for SARS-CoV-2.

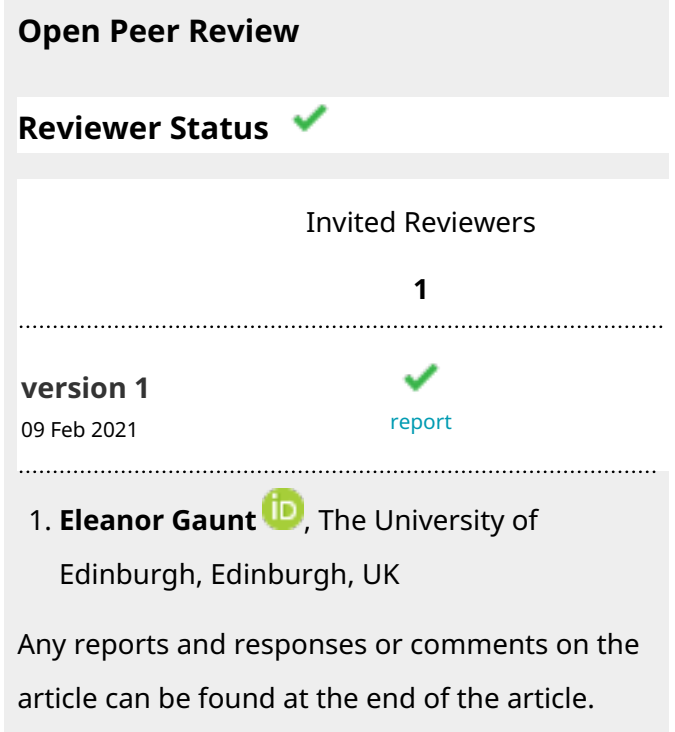




\title{
Keywords
}

Human coronavirus, OC43, NL63, 229E, Transmission, Households,

Virus shedding

\section{Q. This article is included in the Coronavirus}

\author{
(COVID-19) collection.
}

Corresponding authors: Dickson Machira Nyaguthii (machira.dickson@gmail.com), Grieven P. Otieno (grievenoti@gmail.com)

Author roles: Nyaguthii DM: Formal Analysis, Methodology, Validation, Visualization, Writing - Original Draft Preparation, Writing Review \& Editing; Otieno GP: Data Curation, Formal Analysis, Methodology, Validation, Visualization, Writing - Original Draft

Preparation, Writing - Review \& Editing; Kombe IK: Formal Analysis, Methodology, Validation, Writing - Review \& Editing; Koech D: Investigation, Methodology, Project Administration, Writing - Review \& Editing; Mutunga M: Investigation, Validation, Writing - Review \& Editing; Medley GF: Conceptualization, Investigation, Methodology, Writing - Review \& Editing; Nokes DJ: Conceptualization, Funding Acquisition, Investigation, Methodology, Project Administration, Resources, Supervision, Writing - Review \& Editing; Munywoki PK: Conceptualization, Funding Acquisition, Investigation, Methodology, Project Administration, Resources, Supervision, Writing - Review \& Editing

Competing interests: No competing interests were disclosed.

Grant information: This research was funded by the UK Foreign, Commonwealth and Development Office and Wellcome [220985], and Wellcome [090853].

The funders had no role in study design, data collection and analysis, decision to publish, or preparation of the manuscript.

Copyright: ( 2021 Nyaguthii DM et al. This is an open access article distributed under the terms of the Creative Commons Attribution License, which permits unrestricted use, distribution, and reproduction in any medium, provided the original work is properly cited.

How to cite this article: Nyaguthii DM, Otieno GP, Kombe IK et al. Infection patterns of endemic human coronaviruses in rural households in coastal Kenya [version 1; peer review: 1 approved] Wellcome Open Research 2021, 6:27

https://doi.org/10.12688/wellcomeopenres.16508.1

First published: 09 Feb 2021, 6:27 https://doi.org/10.12688/wellcomeopenres.16508.1 


\section{Introduction}

Four endemic species of human coronavirus (hCoV), HKU1, OC43, NL63 and 229E, are widespread and associated primarily with mild acute respiratory illness ${ }^{1}$. Infections with endemic hCoVs are reportedly more severe in young children and the elderly ${ }^{2,3}$. In the last two decades, three new members of this virus family have emerged as human pathogens; severe acute respiratory syndrome coronavirus (SARS-CoV) ${ }^{4}$, Middle East respiratory syndrome coronavirus (MERS-CoV) ${ }^{5}$ and most recently SARS-CoV-2 ${ }^{6}$. The pandemic spread and continued circulation beyond the initial wave of infection suggests a potential for SARS-CoV-2 to become resident within the human population. A focus on the natural history and transmission characteristics of current little-studied endemic species of $\mathrm{hCoV}$ may give insight to the future behaviour of this emergent relative ${ }^{7}$

Using data from a study of 47 households in rural Kenya, we have previously reported baseline data on the occurrence of $\mathrm{hCoV}^{8}$ and a detailed analysis of reinfection with hCoV-NL63. In the present study, we investigate the natural history of infection and transmission patterns of three endemic $\mathrm{hCoV}$ within these households.

\section{Methods}

\section{Household data}

This study utilizes data from a prospective household-based cohort study conducted in one administrative location within the Kilifi health and demographic surveillance system (KHDSS) $)^{8,10}$ on the Kenyan coast. The study design and methods have been described elsewhere ${ }^{8,11}$. Briefly, with a primary objective of characterising 'who infects whom' with respiratory syncytial virus (RSV), households with an infant born after the end of the 2008/2009 RSV season (referred to as the study infant) and at least one elder sibling (aged $<13$ years) were enrolled. The study period spanned a complete RSV season from $8^{\text {th }}$ December 2009 to $5^{\text {th }}$ June 2010. Nasopharyngeal specimens (NPS) were collected from all household members irrespective of symptoms, once a week in the first four weeks and twice-a-week thereafter until the study end. A household was defined as members (who need not be related) of one or more building units who share the same cooking facility. The study had a good retention rate $(>80 \%)$ of households and of individuals over the study period $^{11}$.

The study was approved by the Kenyan National Ethical Review Committee and the University of Warwick's Biomedical Research Ethical Committee in the United Kingdom. Individual written informed consent was obtained from all study participants aged $\geq 18$ years. For those $<18$ years old, written consent was obtained from the parent or guardian.

\section{Molecular testing of the NPS collections using multiplex RT-PCR assay}

A previously described real time multiplex RT-PCR (mPCR) assay with targets for 15 respiratory viruses was used ${ }^{12}$. The target pathogens were human coronavirus (hCoV species (also called types) OC43, NL63 and 229E), RSV A and B, rhinovirus
(RV), adenovirus (AdV), parainfluenza virus (types 1-4), influenza virus (types $\mathrm{A}, \mathrm{B}$ and $\mathrm{C}$ ) and human metapneumovirus (hMPV). A preliminary screen of the NPS showed the last three virus groups were uncommon during the surveillance period and hence not screened for the remainder of the NPS collections $^{8}$. A specimen with a cycle threshold $(\mathrm{Ct})$ value of $\leq 35.0$ for a specific virus target was considered positive.

\section{Statistical analysis}

Data analyses were undertaken in STATA Version 13.0 (StataCorp, College Station, Texas, USA). Descriptive statistics for continuous variables are presented as mean $( \pm$ standard deviation) and median (interquartile range (IQR)). Categorical variables were summarised using counts and proportions and the chi-square test of association was used to examine the independence. The Mood's median test was used to investigate equality of median times across levels of categorical variables. Two or more groups were compared using test for equality of proportions.

Type-specific individual hCoV infection episodes were defined as a period with positive mPCR result(s) of the same type with no more than 14 days apart ${ }^{13}$. Episodes where no samples were collected and tested for $>7$ days before or after the infection episode were considered left- or right-censored, respectively. An episode was considered symptomatic if the individual was identified with any of the following symptoms during the infection episode; cough, runny nose, sore throat, nasal flaring, indrawing, crackles, wheeze, fever, unable to feed, head nodding, lethargy, unable to talk, cyanosis or difficulty breathing. Co-infection was assigned when within the hCoV infection episode an NPS collection was MPCR positive for a different hCoV species or another of the viruses tested, namely; RSV, RV, or AdV. Detection of two or more individual infection episodes by the same hCoV type in a household within a span of 14 days constituted a household outbreak. For each household hCoV introduction, a primary (index) case was defined as the first person(s) to test positive for $\mathrm{hCoV}$ by mPCR while secondary case(s) were the rest of the members who are part of the same household outbreak. For individuals with multiple hCoV infection episodes, reinfections were classified as either homologous (same hCoV species) or heterologous (different hCoV species) with respect to previously detected species during the study period. As an example, if an individual has three infections in the temporal order OC43, NL63 and OC43, then the second infection episode would be heterologous to the first, and the third homologous to the first infection episode and heterologous to the second episode.

Durations of virus shedding were estimated using a midpoint method which was defined as the period starting midway between the first positive sample and the previous negative sample and ending midway between the last positive sample and the subsequent negative sample. Further details on this approach are provided elsewhere ${ }^{13}$. Kaplan Meir (KM) curves were used to describe the survival functions (time to end of virus shedding) by different categorical variables across the three endemic $\mathrm{hCoV}$ types. Adjusted hazard ratios (aHR) obtained from 
multivariable Cox proportional hazards $(\mathrm{PH})$ models were used to estimate the influence of several factors on the duration of shedding and symptoms. Logistic regression models were used to identify risk factors for spread of infection from the primary cases to other household members. The risk factors considered were age, sex, household size, presence of respiratory symptoms, presence of other respiratory pathogens and peak viral load in an infection episode. The peak/highest viral load was defined as the lowest $\mathrm{Ct}$ value in an individual infection episode and was categorised into three levels; low $(>=30)$, medium (20-29) and high $(<20)$. To account for clustering either at individual or household level, robust cluster variance estimator was used in the Cox $\mathrm{PH}$ and logistic regression models discussed above.

\section{Results}

\section{Baseline characteristics}

A total of 483 individuals from 47 households had NPS collected over the six-month period. The mean number of household members was $10.5 \quad(\mathrm{SD}=6.5)$ classified into small
(4-7 members), medium (8-16 members) and large (17- 37 members). The median age of participants at the start of sampling was 10.7 years (IQR: 4.0 - 23.4). The cohort had 214 (44.3\%) male participants. Of the 47 study infants, the average age at the start of the study was $3.9(\mathrm{SD}=2.6)$ months and $22(46.8 \%)$ of the infants were males. A total of 16,918 NPS from 483 individuals were successfully tested for OC43, 229E and NL63. The median number of NPS collected from study participants was 41 (IQR: 30 - 44).

Of the 16918 samples tested, $1274(7.5 \%)$ were positive for any of the three hCoV: $651(3.8 \%), 418(2.5 \%)$ and $241(1.4 \%)$ samples were positive for OC43, NL63 and 229E, respectively. Seven $(0.04 \%)$ NPS collections were positive for both OC43 and NL63, $17(0.1 \%)$ were positive for both OC43 and 229E and $13(0.08 \%)$ were positive for both NL63 and 229E. Only one sample was positive for all three hCoV tested. Higher individual crude attack rates (Table 1) were seen in school going children $(129 / 169 ; 76.3 \%)$, males $(160 / 214 ; 74.8 \%)$ and younger individuals ( $<1$ year; 42/55, 76.4\%, 1-4 years;

Table 1. Crude individual attack rates for the hCoV infections by various characteristics.

\begin{tabular}{|c|c|c|c|c|c|c|c|c|c|c|}
\hline \multirow[t]{2}{*}{ Characteristics } & \multirow[b]{2}{*}{ Categories } & \multirow[b]{2}{*}{$N$} & \multicolumn{2}{|c|}{ Any hCoV } & \multicolumn{2}{|c|}{ OC43 } & \multicolumn{2}{|c|}{ NL63 } & \multicolumn{2}{|c|}{$229 E$} \\
\hline & & & $n$ & $\%$ & $n$ & $\%$ & $n$ & $\%$ & $n$ & $\%$ \\
\hline Overall & & 483 & 346 & 71.6 & 215 & 44.4 & 163 & 33.7 & 119 & 24.6 \\
\hline \multirow[t]{5}{*}{ Age in years } & $<1$ & 55 & 42 & 76.4 & 30 & 54.6 & 16 & 29.1 & 16 & 29.1 \\
\hline & $1-4$ & 82 & 64 & 78.0 & 45 & 54.9 & 28 & 34.2 & 24 & 29.3 \\
\hline & $5-14$ & 163 & 125 & 76.7 & 83 & 50.9 & 65 & 39.9 & 40 & 24.5 \\
\hline & $15-39$ & 141 & 93 & 66.0 & 51 & 36.2 & 42 & 29.8 & 29 & 20.6 \\
\hline & $\geq 40$ & 42 & 22 & 52.4 & 6 & 14.3 & 12 & 28.6 & 10 & 23.8 \\
\hline \multirow{6}{*}{$\begin{array}{l}\text { Relation to the } \\
\text { study infant }\end{array}$} & Self & 47 & 37 & 78.7 & 27 & 57.5 & 13 & 27.7 & 15 & 31.9 \\
\hline & Sibling & 162 & 124 & 76.5 & 87 & 53.7 & 55 & 34.0 & 40 & 24.7 \\
\hline & Cousin & 124 & 91 & 73.4 & 56 & 45.2 & 51 & 41.1 & 28 & 22.6 \\
\hline & Mother & 46 & 27 & 58.7 & 16 & 34.8 & 13 & 28.6 & 11 & 23.9 \\
\hline & Father & 30 & 17 & 56.7 & 7 & 23.3 & 7 & 23.3 & 5 & 16.7 \\
\hline & $\begin{array}{l}\text { Other HH } \\
\text { members }\end{array}$ & 74 & 50 & 67.6 & 22 & 29.7 & 24 & 32.4 & 20 & 27.0 \\
\hline \multirow[t]{2}{*}{ Sex } & Female & 269 & 186 & 69.1 & 121 & 45.0 & 89 & 33.1 & 65 & 24.2 \\
\hline & Male & 214 & 160 & 74.8 & 94 & 43.9 & 74 & 34.6 & 54 & 25.2 \\
\hline \multirow[t]{2}{*}{ School going } & No & 314 & 217 & 69.1 & 128 & 40.8 & 104 & 33.1 & 76 & 24.2 \\
\hline & Yes & 169 & 129 & 76.3 & 87 & 51.5 & 59 & 34.9 & 43 & 25.4 \\
\hline \multirow{4}{*}{$\begin{array}{l}\text { Number of } \\
\text { individuals per } \\
\text { HH (household } \\
\text { sizes) }\end{array}$} & 4 to 7 & 95 & 75 & 79.0 & 50 & 52.6 & 37 & 39.0 & 21 & 22.1 \\
\hline & 8 to10 & 120 & 77 & 64.2 & 53 & 44.2 & 29 & 24.2 & 26 & 21.7 \\
\hline & 11 to 16 & 144 & 97 & 67.4 & 48 & 33.3 & 49 & 34.0 & 40 & 27.8 \\
\hline & 17 to 37 & 124 & 97 & 78.2 & 64 & 51.6 & 48 & 38.7 & 32 & 25.8 \\
\hline
\end{tabular}


64/82, 78.0\% and 5-14 years; 125/163, 76.7\%) (Extended data: Supplementary Figure S1) and individuals residing small $(75 / 95,79.0 \%)$ and large households $(97 / 124,78.2 \%)$.

Symptomatic individuals contributed to 410 (32.2\%) of the 1274 samples that were positive for any $\mathrm{HCoV}$ and 3150 $(20.1 \%)$ of $15645 \mathrm{hCoV}$ negative samples. Symptomatic individuals contributed to 240 (36.9\%), $132(31.6 \%)$ and $47(19.5 \%)$ of the total number of samples that tested positive for OC43, NL63 and 229E, respectively, and correspondingly 3320 (20.4\%), $3428(20.8 \%)$ and $3513(21.1 \%)$ of samples that tested negative. There was a statistically significant association between the presence of respiratory symptoms during sampling times and detection of any hCoV $\left(\chi_{(1)}^{2}=102.9\right.$, p-value $\left.<0.001\right)$, OC43 $\left(\chi_{(1)}^{2}=102.1\right.$, p-value $\left.<0.001\right)$ and NL63 $\left(\chi_{(1)}^{2}=28.6\right.$, p-value $<0.001)$ but not 229E $\left(\chi_{(1)}^{2}=0.35\right.$, p-value $\left.=0.555\right)$.

\section{HCoV infection episodes}

The pattern of shedding of each of the three hCoV types and of all hCoVs, is displayed in Figure 1. Over the study period, $346(71.6 \%)$ of the 483 individuals experienced one or more $\mathrm{hCoV}$ infection episodes. The total number of individual infection episodes was 260 for OC43, 216 for NL63, 140 for $229 \mathrm{E}$ and 629 for any hCoV type. Of these the number of episodes symptomatic was $116(44.5 \%)$ for OC43, $85(39.4 \%)$ for NL63, $35(25.0 \%)$ for $229 \mathrm{E}$ and 228 (36.3\%) for any hCoV type. The proportion of symptomatic episodes differed by hCoV type $\left(\chi_{(3)}^{2}=15.7\right.$, p-value $\left.=0.001\right)$ and by age for any hCoV type $\left(\chi_{(4)}^{2}=99.35, \mathrm{p}\right.$-value $\left.<0.001\right)$ and each of the three hCoV types $\left(\mathrm{OC} 43 ; \chi_{(4)}^{2}=54.4, \mathrm{p}\right.$-value $<0.001$, NL63; $\chi_{(4)}^{2}=34.7$, p-value $<0.001$ and $229 \mathrm{E} ; \chi_{(4)}^{2}=25.5$, p-value $<0.001)$. Of the total episodes, 29 (11.2\%), 51 (23.6\%), $28(20 \%)$ and $105(16.7 \%)$ of OC43, NL63, 229E or any hCoV infection episodes, respectively were either right or left-censored and were excluded in survival analysis.

On average, the peak viral load of the individual infection episodes was higher in symptomatic compared to asymptomatic episodes (Figure 2). This was supported by linear regression model, adjusted for age, fitted on the peak viral load showing symptomatic infection episodes had a higher viral load (lower $\mathrm{Ct}$ values) compared to asymptomatic episodes for OC43 $(\beta=-4.16,95 \% \mathrm{CI}=-5.55,-2.77, \mathrm{p}$-value $<0.001), \quad \mathrm{NL63}$ $(\beta=-2.74,95 \% \quad \mathrm{CI}=-5.06,-0.43, \mathrm{p}$-value $=0.020), \quad 229 \mathrm{E}$ $(\beta=-5.79,95 \% \mathrm{CI}=-9.88,-1.70, \mathrm{p}$-value $=0.006)$ and any $\mathrm{hCoV}(\beta=-3.11,95 \% \mathrm{CI}=-4.50,-1.72$, $\mathrm{p}$-value $<0.001)$.
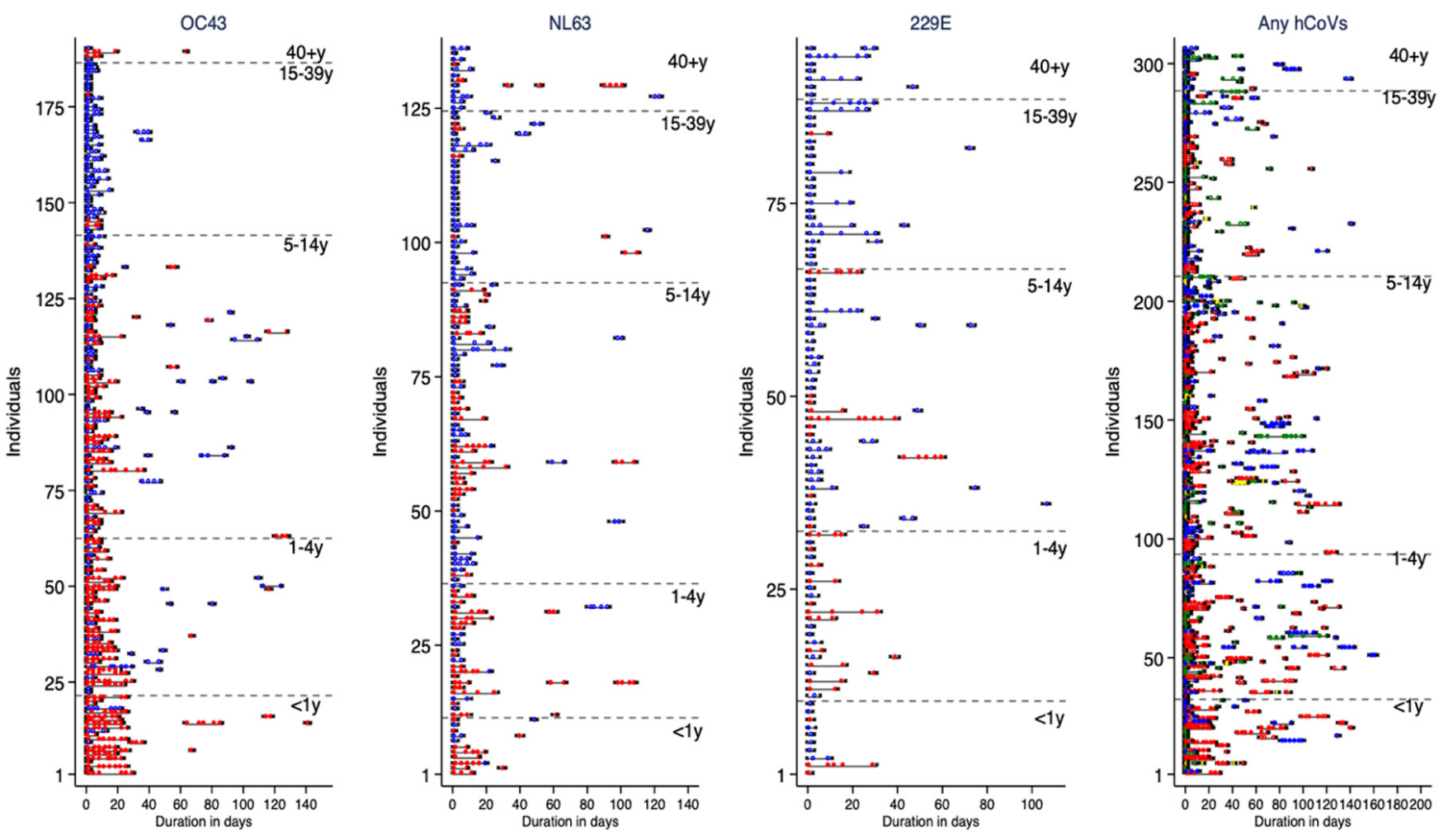

Figure 1. Individual infection episodes showing the duration of shedding hCoV type. The grey lines indicate duration of the episodes, dots indicate positive samples within an episode and the crosses at both ends of the line denote the start and end of the infection episodes. For the first three graphs (OC43, NL63 and 229E) symptomatic episodes are shown by red filled dots while asymptomatic episodes are shown by blue unfilled dots. In the final graph, red, blue, green and yellow dots indicate samples positive for OC43, NL63, 229E and HCoVHCoV coinfection. Filled dots indicate symptomatic episodes while unfilled dots are asymptomatic episodes. 
OC43

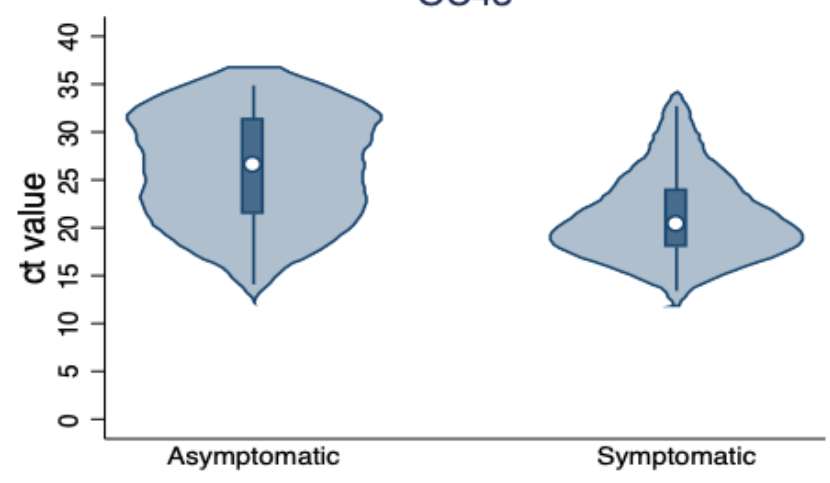

229E

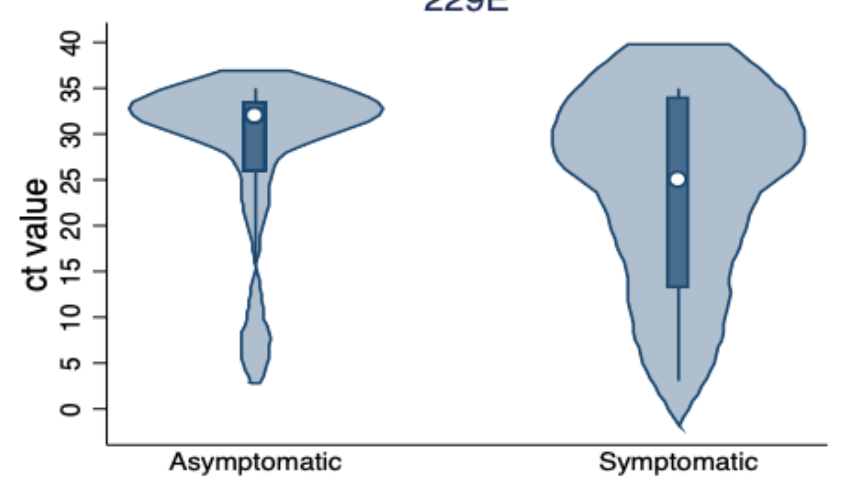

OC43

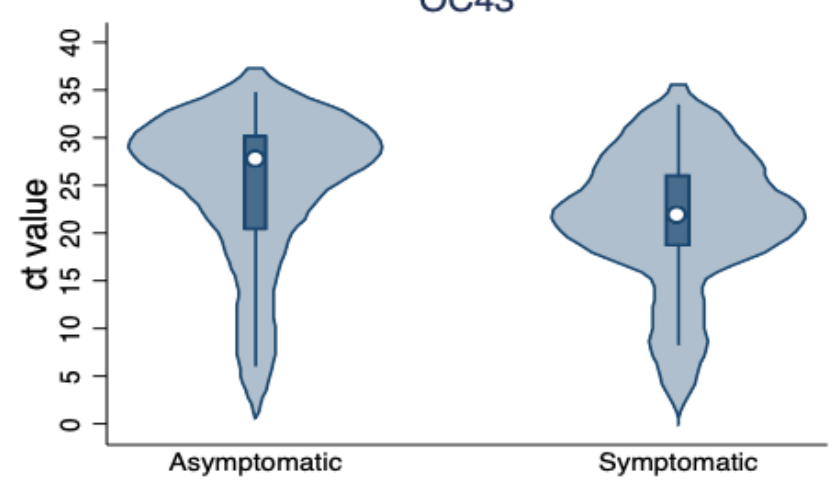

Any hCoV

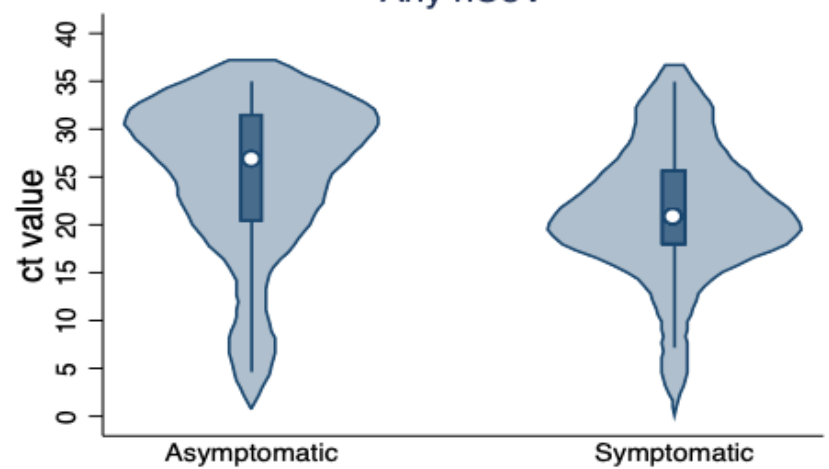

Figure 2. Violin plots showing the distribution of the peak viral load (expressed in Ct values) across infection episodes by hCoV type and symptomatic status.

\section{Durations of hCoV shedding and factors influencing shedding patterns}

The duration of virus shedding varied by hCoV type with the longest median duration observed for OC43 (7.5 days, IQR: $3.5-13.5)$ and the shortest median duration for 229E (3.5 days, IQR: 3.5 - 7.0) (Figure 3). The results of the survival analysis of shedding durations are shown in Table 2. For OC43, the rate of recovery from an infection episode, compared to children aged $<1$ year, was higher in children aged 5-14 years $(\mathrm{aHR}=2.21,95 \% \mathrm{CI}: 1.40-3.47, \mathrm{p}$-value $=<0.001)$, those aged 15-39 years $(\mathrm{aHR}=1.72$, 95\% CI: $1.05-2.83$, p-value $=0.032)$ and older adults 40 years or more $(\mathrm{aHR}=3.44$, 95\% CI: 1.97 - 6.01, p-value <0.001). Age dependence for duration of infection episodes was not observed for NL63, 229E and pooled hCoV type analysis. Lower rates of recovery from OC43 virus shedding (i.e. longer shedding durations) were observed among symptomatic (compared to asymptomatic) individuals $(\mathrm{aHR}=0.56,95 \% \mathrm{CI}: 0.39-0.81$, p-value $=0.002)$, and individuals with medium peak viral load (aHR=0.32, 95\% CI: 0.22-0.47, p-value <0.001) and high peak viral load $(\mathrm{aHR}=0.22,95 \%$ CI: 0.14-0.36, p-value <0.001) compared to individuals with low peak viral load. Recovery rates from NL63 infection episode was dependent on detection of other viral pathogens within the same infection episode $(\mathrm{aHR}=$
0.54, 95\% CI: $0.34-0.87$, p-value $=0.011)$, being symptomatic $(\mathrm{aHR}=0.67,95 \% \mathrm{CI}: 0.50-0.90, \mathrm{p}$-value $=0.009)$, and medium $(\mathrm{aHR}=0.49,95 \% \mathrm{CI}: 0.33-0.74, \mathrm{p}$-value $=0.001)$ and high $(\mathrm{aHR}=0.37,95 \% \mathrm{CI}: 0.24-0.59$, p-value $<0.001)$ peak viral load in an infection episode. For 229E, having medium $(\mathrm{aHR}=0.49, \quad 95 \% \quad \mathrm{CI}: \quad 0.30 \quad-0.78, \quad \mathrm{p}$-value $=0.003)$ and high $(\mathrm{aHR}=0.21,95 \% \mathrm{CI}: 0.11-0.40$, p-value $=<0.001)$ peak viral load significantly affected the rate of recovery from an infection episode. The KM curves for each factor are presented in Extended data: Supplementary Figures S2-S5.

\section{Duration of symptomatic period}

The median duration of symptoms (Extended data: Supplementary Table S1) was 7.0, 4.0, 3.5 and 4.0 days, for OC43, NL63, $229 \mathrm{E}$ and any hCoV, respectively. For any hCoV median durations tended to decline with increasing age, increase in the presence of other respiratory viruses and increase for high peak viral load. There was some variation between $\mathrm{hCoV}$ type.

The rate of recovery from symptoms (Extended data: Supplementary Table S2) within any $\mathrm{hCoV}$ infection episodes increased with age; $1-4$ years $(\mathrm{aHR}=1.45,95 \% \mathrm{CI}: 1.03-2.04$, $\mathrm{p}$-value $=0.034), 5-14$ years $\quad(\mathrm{aHR}=1.64,95 \% \mathrm{CI}: 1.12-2.39$, p-value $=0.010), 15-39$ years $(\mathrm{aHR}=2.25,95 \% \mathrm{CI}: 1.30-3.89$, 

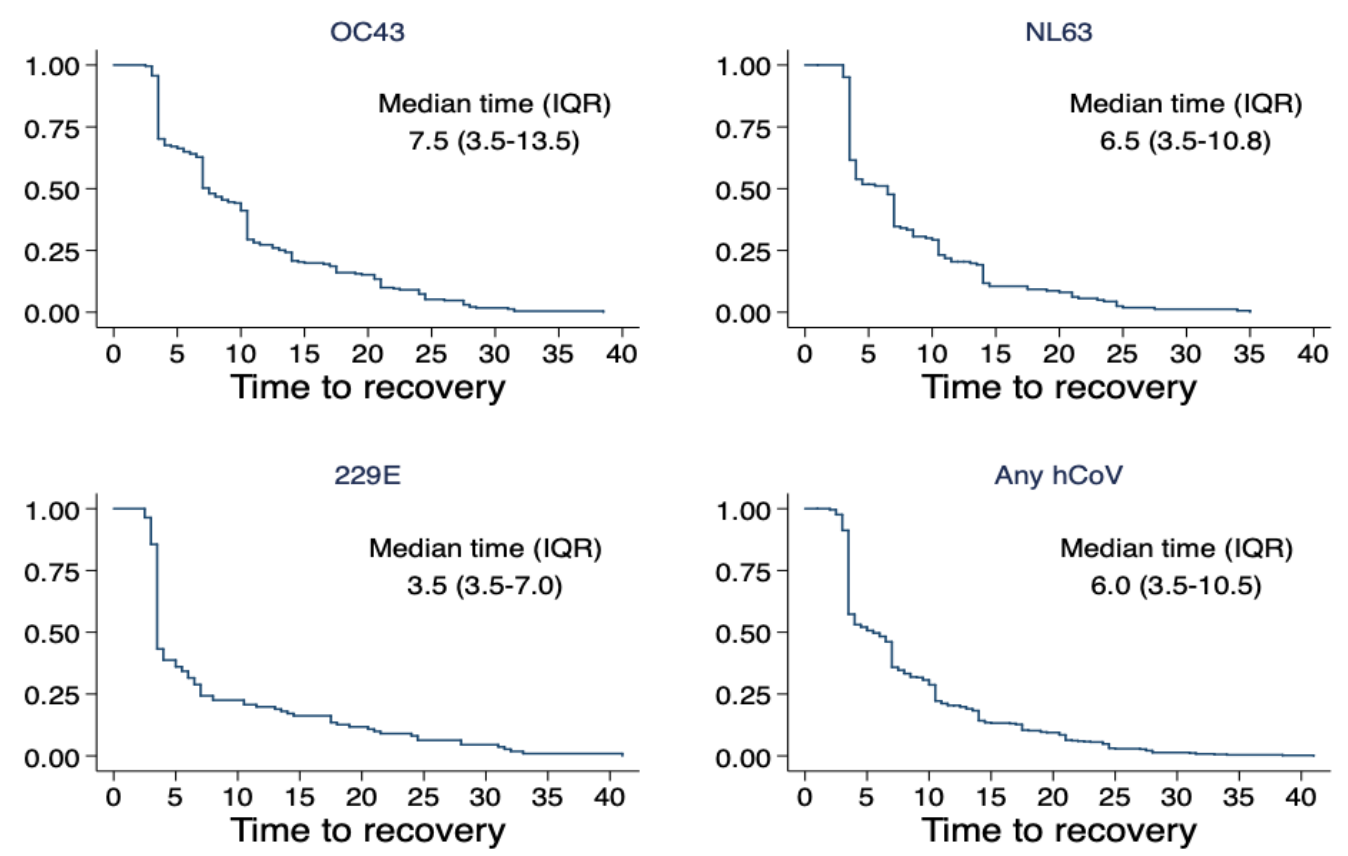

Figure 3. Time to recovery of hCoV infections for OC43, NL63, NL63 and any hCoV based on survival analysis (Kaplan Meir curves).

p-value $=0.003) ; 40$ years and above $(\mathrm{aHR}=1.61,95 \% \mathrm{CI}: 1.10$ - 2.37, p-value=0.014). A similar pattern was observed on OC43 alone out of the three hCoVs. Infection episodes with a coinfection with another virus had lower rates of recovery from symptoms for 229E (aHR=0.33, 95\% CI: $0.17-0.63$, $\mathrm{p}$-value $=0.001)$ and any hCoV $(\mathrm{aHR}=0.71,95 \% \mathrm{CI}: 0.55$ $0.91, \mathrm{p}$-value $=0.006$ ). The rate of symptoms clearance within OC43 infection episodes was influenced by medium peak viral load $(\mathrm{aHR}=0.15$, 95\% CI $0.07-0.31$, p-value $<0.001)$ and high peak viral load $(\mathrm{aHR}=0.14$ 95\% CI: $0.07-0.29$, p-value<0.001). Similarly, a lower recovery rate was observed for any hCoV infection episodes with medium peak viral load (aHR 0.44, 95\% CI: $0.29-0.68$, p-value < 0.001) and high peak viral load $(\mathrm{aHR}=0.35,0.23-0.54$, $\mathrm{p}$-value $<0.001)$.

\section{Reinfection}

Details of reinfections in the study cohort are given in Table 3. Of 483 study individuals, $346(71.6 \%)$ experienced one or more infection episodes and 171 (35\%) experienced multiple infection episodes for any hCoV type. Of the 215, 163, and 119 individuals who had first infections of OC43, NL63 and 229E, respectively, a corresponding 35 (16.3\%), $44(27.0 \%)$ and $20(16.8 \%)$, experienced one or more homologous reinfections. In summation, a total of 497 first infections with OC43, NL63 and 229E were observed of which $99(19.9 \%)$ were re-infected at least once with the homologous type. Of the 629 episodes, $346(55.0 \%)$ were first and $283(45.0 \%)$ secondary, infections and 154/283 (54.4\%) reinfections were of homologous type. Analysing the total infections by type, the proportion of homologous reinfection episodes varied $\left(\chi_{(1)}^{2}=6.12, p\right.$-value $\left.=0.047\right)$ by type (17.3\% of 260 OC43 episodes, $24.5 \%$ of 216 NL63 episodes and $15.0 \%$ of 140 episodes due to 229E). In addition, $48(31.2 \%)$ of the 154 homologous reinfection episodes due to any $\mathrm{hCoV}$ were symptomatic, compared to $56(43.4 \%)$ of the 129 heterologous reinfections. There was no difference $\left(\chi_{(1)}^{2}=0.09, \mathrm{p}\right.$-value $\left.=0.764\right)$ in the median time to reinfection between homologous (41 days, IQR: 19-73 days) and heterologous (40 days, IQR: 23-60 days) infection episodes. In the period between end of the first infection episode and start of the first reinfection episode, a total of $16(9.4 \%)$ did not have any swabs taken, possibly indicating a continuation of the first episode, while 9 (5.3\%), 8 (4.7\%), $14(8.2 \%)$ and $124(72.5 \%)$ had $1,2,3$ and $\geq 4$ PCR negative samples respectively out of the 171 individuals with multiple infections.

There was no difference in the proportion of symptomatic episodes in the first infection episodes (124/346, 35.8\%) compared to reinfections $(104 / 283,36.8 \%)$ (p-value $=0.7952)$. Disaggregation of symptomatic infection episodes by hCoV type showed that the contribution of each pathogen to the first 124 symptomatic episodes varied; OC43 (58.1\%), NL63 (26.6\%), $229 \mathrm{E}(14.5 \%)$ and $\mathrm{hCoV}-\mathrm{hCoV}$ coinfection (0.8\%). Similarly, out of the 104 symptomatic reinfections episodes, there was a variation in the proportion of hCoV type; OC43 $(36.5 \%)$, NL63 (44.2\%), 229E (12.5\%) and hCoV- hCoV coinfection $(6.7 \%)$.

\section{Transmission of hCoV in households}

All the 47 households had at least one of the three hCoV detected while hCoV-OC43, NL63 and 229E were detected 
Table 2. Factors influencing the recovery rate of hCoV infections from multivariable cox proportional hazards model analysis.

\begin{tabular}{|c|c|c|c|c|c|c|c|c|c|}
\hline \multirow[t]{2}{*}{ Characteristics } & \multirow[t]{2}{*}{ Categories } & \multicolumn{2}{|c|}{ OC43 } & \multicolumn{2}{|c|}{ NL63 } & \multicolumn{2}{|c|}{$229 E$} & \multicolumn{2}{|c|}{ Any hCoV } \\
\hline & & $\begin{array}{c}\text { aHR } \\
(95 \% \mathrm{CI})\end{array}$ & p-value & $\begin{array}{c}\text { aHR } \\
(95 \% \mathrm{CI})\end{array}$ & p-value & $\begin{array}{c}\text { aHR } \\
(95 \% \mathrm{CI})\end{array}$ & p-value & $\begin{array}{c}\text { aHR } \\
(95 \% \mathrm{CI})\end{array}$ & p-value \\
\hline \multirow[t]{2}{*}{ Sex } & Female & Ref & & Ref & & Ref & & Ref & \\
\hline & Male & $\begin{array}{c}1.06 \\
(0.83-1.34)\end{array}$ & 0.634 & $\begin{array}{c}1.22 \\
(0.90-1.66)\end{array}$ & 0.201 & $\begin{array}{c}0.90 \\
(0.64-1.26)\end{array}$ & 0.549 & $\begin{array}{c}1.07 \\
(0.91-1.27)\end{array}$ & 0.397 \\
\hline \multirow[t]{5}{*}{ Age group (in years) } & $<1 \mathrm{y}$ & Ref & & Ref & & Ref & & Ref & \\
\hline & $1-4 y$ & $\begin{array}{c}1.49 \\
(0.96-2.30)\end{array}$ & 0.075 & $\begin{array}{c}0.60 \\
(0.28-1.28)\end{array}$ & 0.186 & $\begin{array}{c}1.00 \\
(0.47-2.13)\end{array}$ & 0.999 & $\begin{array}{c}1.08 \\
(0.75-1.56)\end{array}$ & 0.672 \\
\hline & $5-14 y$ & $\begin{array}{c}2.21 \\
(1.40-3.47)\end{array}$ & $<0.001$ & $\begin{array}{c}0.69 \\
(0.32-1.48)\end{array}$ & 0.341 & $\begin{array}{c}1.04 \\
(0.57-1.95)\end{array}$ & 0.877 & $\begin{array}{c}1.31 \\
(0.92-1.88)\end{array}$ & 0.143 \\
\hline & $15-39 y$ & $\begin{array}{c}1.72 \\
(1.05-2.83)\end{array}$ & 0.032 & $\begin{array}{c}0.99 \\
(0.46-2.12)\end{array}$ & 0.976 & $\begin{array}{c}0.79 \\
(0.39-1.58)\end{array}$ & 0.504 & $\begin{array}{c}1.13 \\
(0.76-1.68)\end{array}$ & 0.552 \\
\hline & $\geq 40 y$ & $\begin{array}{c}3.44 \\
(1.97 \\
-6.01)\end{array}$ & $<0.001$ & $\begin{array}{c}0.95 \\
(0.43 \\
-2.09)\end{array}$ & 0.902 & $\begin{array}{c}0.90 \\
(0.47-1.71)\end{array}$ & 0.739 & $\begin{array}{c}1.27 \\
(0.76-2.11)\end{array}$ & 0.370 \\
\hline \multirow{2}{*}{$\begin{array}{l}\text { Presence of other } \\
\text { respiratory viruses }\end{array}$} & No & Ref & & Ref & & Ref & & Ref & \\
\hline & Yes & $\begin{array}{c}0.98 \\
(0.73-1.32)\end{array}$ & 0.902 & $\begin{array}{c}0.54 \\
(0.34-0.87)\end{array}$ & 0.011 & $\begin{array}{c}0.70 \\
(0.47-1.04)\end{array}$ & 0.077 & $\begin{array}{c}0.80 \\
(0.65-0.97)\end{array}$ & 0.026 \\
\hline \multirow[t]{2}{*}{ Symptomatic } & No & Ref & & Ref & & Ref & & Ref & \\
\hline & Yes & $\begin{array}{c}0.56 \\
(0.39-0.81)\end{array}$ & 0.002 & $\begin{array}{c}0.67 \\
(0.50-0.91)\end{array}$ & 0.009 & $\begin{array}{c}0.71 \\
(0.47-1.07)\end{array}$ & 0.103 & $\begin{array}{c}0.62 \\
(0.51-0.76)\end{array}$ & $<0.001$ \\
\hline \multirow[t]{3}{*}{ Peak viral load } & Low & Ref & & Ref & & Ref & & Ref & \\
\hline & Medium & $\begin{array}{c}0.32 \\
(0.22-0.47)\end{array}$ & $<0.001$ & $\begin{array}{c}0.49 \\
(0.33-0.74)\end{array}$ & 0.001 & $\begin{array}{c}0.49 \\
(0.30-0.78)\end{array}$ & 0.003 & $\begin{array}{c}0.44 \\
(0.34-0.57)\end{array}$ & $<0.001$ \\
\hline & High & $\begin{array}{c}0.22 \\
(0.14-0.36)\end{array}$ & $<0.001$ & $\begin{array}{c}0.37 \\
(0.24-0.59)\end{array}$ & $<0.001$ & $\begin{array}{c}0.21 \\
(0.11-0.40)\end{array}$ & $<0.001$ & $\begin{array}{c}0.31 \\
(0.23-0.42)\end{array}$ & $<0.001$ \\
\hline \multirow[t]{4}{*}{ HCoV type } & OC43 & - & - & - & - & - & - & Ref & \\
\hline & NL63 & - & - & - & - & - & - & $\begin{array}{c}1.17 \\
(0.95-1.43)\end{array}$ & 0.125 \\
\hline & $229 E$ & - & - & - & - & - & - & $\begin{array}{c}1.02 \\
(0.78-1.35)\end{array}$ & 0.861 \\
\hline & $\begin{array}{c}\text { hCoV } \\
\text { - hCoV } \\
\text { coinfection }\end{array}$ & - & - & - & - & - & - & $\begin{array}{c}2.64 \\
(1.97-3.55)\end{array}$ & $<0.001$ \\
\hline
\end{tabular}

Key: aHR, adjusted Hazard Ratio; hCoV-hCoV coinfection denotes infection episodes in which an individual tested positive for two or more hCoVs.

in $44(93.6 \%), 33(70.2 \%)$ and $30(63.8 \%)$ of the households, respectively. There were 78, 48, 59 and 201 household introductions for OC43, NL63, 229E and any hCoV, respectively. Siblings and cousins, predominantly of school going age, to the study infants were index cases for $59.0 \%, 64.6 \%, 52.5 \%$ and $53.7 \%$ of OC43, NL63, 229E and any hCoV household introductions, respectively (Figure 4). Out of the total number of household introductions, 46 (59.0\%), 30 (62.5\%), $23(39.0 \%)$ and $96(47.8 \%)$ led to secondary infections in 35, 23, 17 and 43 households for OC43, NL63, 229E and any hCoV, respectively. The proportion of secondary infections due to the $3 \mathrm{hCoV}$ types was significantly different across types $\left(\chi_{(2)}^{2}=7.50\right.$, $\mathrm{p}$-value $=0.023$ ).

The risk of generating a secondary case after introduction of any of the three endemic hCoV in the household was higher for index cases whose peak viral load was medium $(\mathrm{aOR}=5.29$, 95\% CI: $2.34-11.96$, p-value $<0.001)$ or high $(\mathrm{aOR}=8.12$, 95\% CI: 2.92 - 22.51, p-value <0.001) compared those with a low peak viral load. However, being a symptomatic index case was not associated with increased risk of infecting other members of the household $(\mathrm{aOR}=0.97,95 \% \mathrm{CI}$ : $0.42-2.21$, 
Table 3. Frequency distribution of individual infection episodes by hCoV type in $\mathbf{4 8 3}$ individuals from a household cohort in rural Kenya.

\begin{tabular}{|c|c|c|c|c|c|c|c|c|c|c|}
\hline & Type & $1 \mathrm{st}$ & 2nd & 3rd & 4th & 5th & $6^{\text {th }}$ & 7th & $\begin{array}{l}\text { Total } \\
\text { reinfection }\end{array}$ & $\begin{array}{l}\text { Total } \\
\text { infection }\end{array}$ \\
\hline \multirow{4}{*}{$\begin{array}{l}\text { Individual hCoV } \\
\text { types episodes }\end{array}$} & OC43 & 215 & 35 & 9 & 1 & - & - & - & 45 & 260 \\
\hline & NL63 & 163 & 44 & 8 & 1 & - & - & - & 53 & 216 \\
\hline & $229 E$ & 119 & 20 & 1 & - & - & - & - & 21 & 140 \\
\hline & All types summation & 497 & 99 & 18 & 2 & - & - & - & & \\
\hline \multirow{2}{*}{$\begin{array}{l}\text { Any hcoV type } \\
\text { episodes }\end{array}$} & Any Homologous & & 66 & 52 & 25 & 8 & 2 & 1 & 154 & \\
\hline & Any infection & 346 & 171 & 73 & 27 & 9 & 2 & 1 & 283 & 629 \\
\hline
\end{tabular}
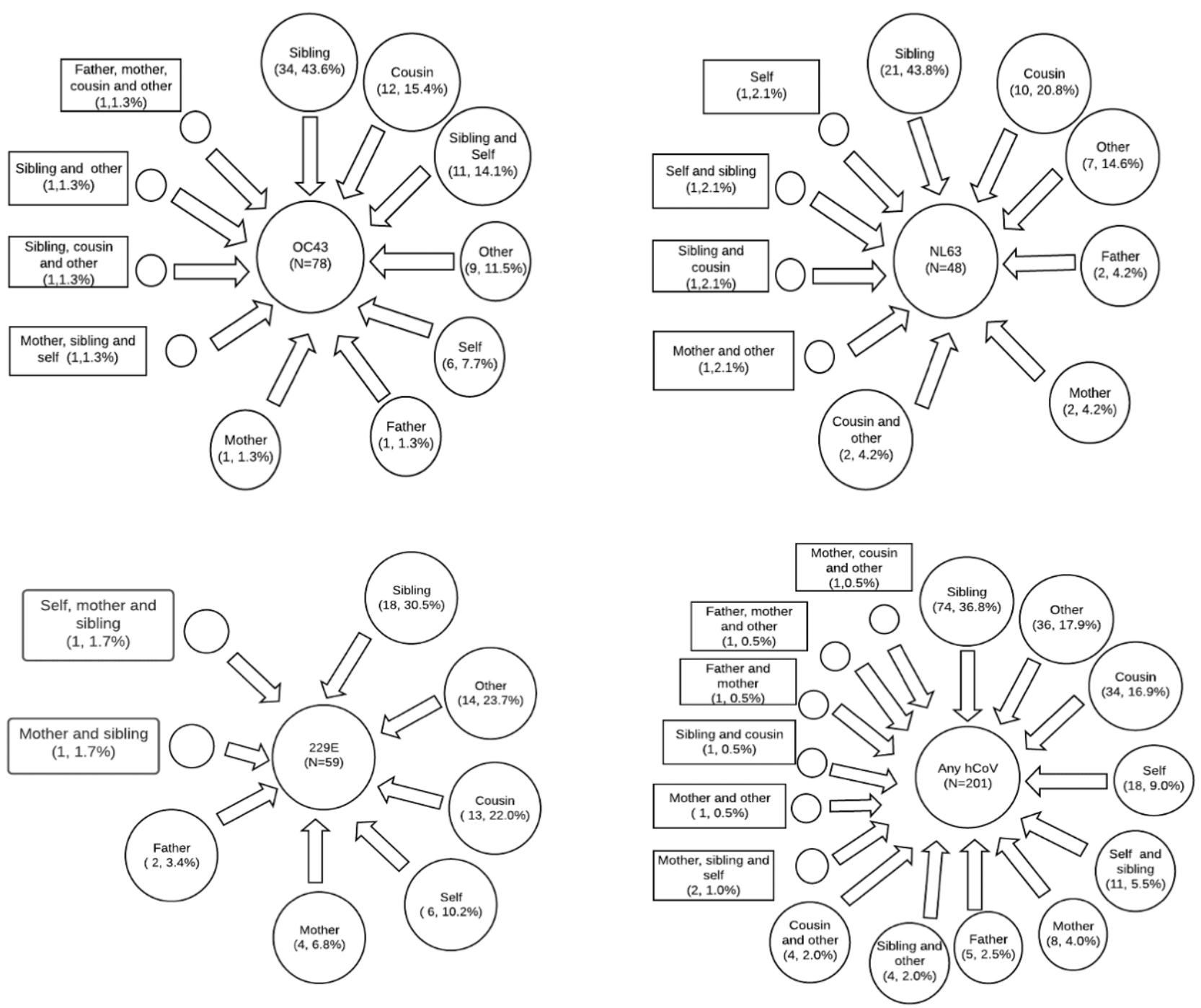

Figure 4. Frequency distribution of who brings hCoV infections in households by HCoV type. 
p-value $=0.933)$ compared to asymptomatic index cases (Extended data: Supplementary Table S3).

\section{Discussion}

Longitudinal studies of households have played an important role in developing understanding of the epidemiology of respiratory viruses ${ }^{7,14}$. Here we continue this approach, reporting an intensive surveillance of 483 household members in rural coastal Kenya ${ }^{11}$, to delineate the natural history of infection and transmission patterns of three endemic coronaviruses (OC43, NL63 and 229E). This involved the application of sensitive molecular diagnostic methods ${ }^{7,14}$, and additionally applied sampling that was frequent and irrespective of observed symptoms $^{8}$. The hCoV types were common in this setting with each of the 47 households, and about $72 \%$ of the enrolled household members, experiencing infection with at least one of three targets over the six months of the study. A note of caution in interpreting the results of this study is that infection status determined by PCR assay is not necessarily indicative of active infection or an individual's infectiousness.

Crude attack rates were highest for hCoV-OC43 and lowest for $229 \mathrm{E}$, higher in general for younger age classes $(<15$ years of age), school-age children and for males. These results are broadly consistent with the findings by Monto et al. who also found highest incidence for OC43, lowest for 229E, and higher incidence among those aged below 5 years for NL63 and OC43 ${ }^{7}$.

The three hCoV types had differing durations of shedding ranging from 3.5 days (229E) to 7.5 days (OC43). However, these median time estimates are influenced by our sampling frequency: predominantly every 3-4 days. The duration of shedding was longer in episodes with high peak virus load and which were symptomatic. Consistent with findings from other studies, we report occurrence of hCoV infection episodes among asymptomatic individuals ${ }^{15-17}$ who had lower viral load $^{18}$ and shorter durations of virus shedding compared to symptomatic episodes. Despite asymptomatic infections being predominant $(>70 \%$ of episodes) the above findings suggest they were less likely to transmit infection compared to symptomatic individuals. The duration of symptomatic episodes was related to peak virus load as reported elsewhere [25] and tended to decline with increasing age.

Participants of all ages had appreciable risk of infection for the three endemic viruses suggesting previous infection does not provide solid immunity. This is supported by our observation that, within the short period of the study, reinfections were common and as frequently of homologous as heterologous type. Overall, $20 \%$ of individuals with a first infection of one or other type, were reinfected by the same type at least once, most commonly for type NL63 (24.5\%). Homologous reinfections were frequently $(>30 \%)$ symptomatic. We report no difference in the proportion of symptomatic cases between the first episodes and reinfection episodes and note that the time to reinfection with homologous was similar to heterologous episodes ( 40 days). Our observations indicate that immunity to reinfection is commonly short lived and does not appear to be type specific. A recent serological study involving 10 adult men detected reinfections from seasonal coronaviruses but most frequently occurring after an interval of 12 months $^{19}$. A limitation of our analysis is that reinfections might in fact have been prolonged shedding from a single infection. This is likely not a major effect as in most presumed reinfections $(>70 \%)$ there were at least 4 PCR test negative results between episodes.

Older children (siblings and cousins) and other adults were the major introducers of $\mathrm{hCoV}$ transmission into the household compared to RSV transmission in the same households whereby older children $(>32 \%)$ were the leading primary cases $^{11}$. Similarly, children have been reported to form the highest proportion of index cases in the USA and $\mathrm{UK}^{7,20}$. However, presence of older adults, children, smokers and individuals with chronic ailments within the households in the UK study was associated with increased household transmission ${ }^{20}$. Secondary transmission of hCoV to other household members upon introduction was high (48\%) for any of the three hCoVs (ranged from $39 \%$ to $62 \%$ across type). This differs from a recent study in England which concluded that the vast majority (>90\%) of observed hCoV infections were acquired outside the household ${ }^{20}$. In our study, the risk of secondary transmission was higher among index cases with high viral loads. Interestingly, there was no significant association between the presence of symptoms among index cases and the risk of secondary transmission, as observed elsewhere ${ }^{20}$.

In conclusion, endemic coronaviruses are common within the household setting, infecting all age groups, and often without eliciting symptoms. Secondary transmission following household introduction is associated with viral load but not, it appears, with symptomatic status, and homologous reinfection is common for all hCoV types.

\section{Data availability}

\section{Underlying data}

Harvard Dataverse: Replication Data for: Infection patterns of endemic human coronaviruses in rural households in coastal Kenya", https://doi.org/10.7910/DVN/CPJ9B421.

As the dataset contains potentially identifying information on participants, it is stored under restricted access. Details on eligibility for access and a request form are available from http://kemri-wellcome.org/about-us/\#ChildVerticalTab_15 for consideration by our Data Governance Committee (dgc@kemriwellcome.org).

The data codebook and scripts are openly available under the terms of the Creative Commons Attribution 4.0 International license (CC-BY 4.0).

\section{Extended data}

Harvard Dataverse: Replication Data for: Infection patterns of endemic human coronaviruses in rural households in coastal Kenya", https://doi.org/10.7910/DVN/CPJ9B421 ${ }^{21}$

This project contains the following extended data:

$$
\text { Supplementary Figures 1-5 }
$$


- $\quad$ Supplementary Tables 1-3

Data are available under the terms of the Creative Commons Attribution 4.0 International license (CC-BY 4.0).

\section{Acknowledgements}

A previous version of this article is available on medRiv: https://doi.org/10.1101/2020.11.03.20225441.
1. Su S, Wong G, Shi W, et al.: Epidemiology, Genetic Recombination, and Pathogenesis of Coronaviruses. Trends Microbiol. 2016; 24(6): 490-502. PubMed Abstract | Publisher Full Text | Free Full Text

2. Falsey AR, Walsh EE, Hayden FG: Rhinovirus and coronavirus infectionassociated hospitalizations among older adults. J Infect Dis. 2002; 185(9): 1338-1341.

PubMed Abstract | Publisher Full Text | Free Full Text

3. Kuypers J, Martin ET, Heugel J, et al.: Clinical disease in children associated with newly described coronavirus subtypes. Pediatrics. 2007; 119(1): e70-76. PubMed Abstract | Publisher Full Text

4. Drosten C, Günther S, Preiser W, et al.: Identification of a Novel Coronavirus in Patients with Severe Acute Respiratory Syndrome. N EnglJ Med. 2003; 348(20): 1967-1976.

PubMed Abstract | Publisher Full Text

5. Zaki AM, van Boheemen S, Bestebroer TM, et al.: Isolation of a Novel Coronavirus from a Man with Pneumonia in Saudi Arabia. N EnglJ Med. 2012; 367(19): 1814-1820. PubMed Abstract | Publisher Full Text

6. Huang C, Wang Y, Li X, et al.: Clinical features of patients infected with 2019 novel coronavirus in Wuhan, China. Lancet. 2020; 395(10223): 497-506. PubMed Abstract | Publisher Full Text | Free Full Text

7. Monto AS, Delonge PM, Callear AP, et al: Coronavirus Occurrence and Transmission Over 8 Years in the HIVE Cohort of Households in Michigan. Infect Dis. 2020; 222(1): 9-16.

PubMed Abstract | Publisher Full Text | Free Full Text

8. Munywoki PK, Koech DC, Agoti CN, et al.: Continuous Invasion by Respiratory Viruses Observed in Rural Households During a Respiratory Syncytial Virus Seasonal Outbreak in Coastal Kenya. Clin Infect Dis. 2018; 67(10): 1559-1567

PubMed Abstract | Publisher Full Text | Free Full Text

9. Kiyuka PK, Agoti CN, Munywoki PK, et al.: Human Coronavirus NL63 Molecular Epidemiology and Evolutionary Patterns in Rural Coastal Kenya.J Infect Dis. 2018; 217(11): 1728-1739.

PubMed Abstract | Publisher Full Text | Free Full Text

10. Scott JAG, Bauni E, Moisi JC, et al.: Profile: The Kilifi Health and Demographic Surveillance System (KHDSS). Int J Epidemiol. 2012; 41(3): 650-657. PubMed Abstract | Publisher Full Text | Free Full Text

11. Munywoki PK, Koech DC, Agoti CN, et al: The Source of Respiratory Syncytia Virus Infection In Infants: A Household Cohort Study In Rural Kenya. J Infect
Dis. 2014; 209(11): 1685-1692.

PubMed Abstract | Publisher Full Text | Free Full Text

12. Hammitt LL, Kazungu S, Welch S, et al.: Added value of an oropharyngeal swab in detection of viruses in children hospitalized with lower respiratory tract infection. J Clin Microbiol. 2011; 49(6): 2318-20. PubMed Abstract | Publisher Full Text | Free Full Text

13. Munywoki PK, Koech DC, Agoti CN, et al.: Influence of age, severity of infection, and co-infection on the duration of respiratory syncytial virus (RSV) shedding. Epidemiol Infect. 2015; 143(4): 804-812. PubMed Abstract | Publisher Full Text | Free Full Text

14. Monto AS, Malosh RE, Petrie JG, et al.: Frequency of Acute Respiratory Illnesses and Circulation of Respiratory Viruses in Households With Children Over 3 Surveillance Seasons. J Infect Dis. 2014; 210(11): 1792-1799. PubMed Abstract | Publisher Full Text | Free Full Text

15. Kusel $\mathrm{MMH}$, de Klerk NH, Holt PG, et al:: Role of respiratory viruses in acute upper and lower respiratory tract illness in the first year of life: a birth cohort study. Pediatr Infect Dis J. 2006; 25(8): 680-686. PubMed Abstract | Publisher Full Text

16. Jansen RR, Wieringa J, Koekkoek SM, et al.: Frequent detection of respiratory viruses without symptoms: toward defining clinically relevant cutoff values. J Clin Microbiol. 2011; 49(7): 2631-2636. PubMed Abstract | Publisher Full Text | Free Full Text

17. Jartti T, Lee WM, Pappas T, et al:: Serial viral infections in infants with recurrent respiratory illnesses. Eur Respir J. 2008; 32(2): 314-320. PubMed Abstract | Publisher Full Text | Free Full Text

18. Milano F, Campbell AP, Guthrie KA, et al.: Human rhinovirus and coronavirus detection among allogeneic hematopoietic stem cell transplantation recipients. Blood. 2010; 115(10): 2088-2094. PubMed Abstract | Publisher Full Text | Free Full Text

19. Edridge AWD, Kaczorowska J, Hoste ACR, et al.: Seasonal coronavirus protective immunity is short-lasting. Nat Med. 2020; 26(11): 1691-1693. PubMed Abstract | Publisher Full Text

20. Beale S, Lewer D, Aldridge RW, et al.: Household transmission of seasonal coronavirus infections: Results from the Flu Watch cohort study [version 1; peer review: 1 approved with reservations]. Wellcome Open Res. 2020; 5: 145. Publisher Full Text

21. Nyaguthii DM, Otieno GP, Kombe IK, et al:: Replication Data for:Infection patterns of endemic human coronaviruses in rural households in coastal Kenya. Harvard Dataverse, V2. 2020. http://wwww.doi.org/10.7910/DVN/CPJ9B4 


\section{Open Peer Review}

\section{Current Peer Review Status:}

\section{Version 1}

Reviewer Report 12 March 2021

https://doi.org/10.21956/wellcomeopenres.18181.r42819

(C) 2021 Gaunt E. This is an open access peer review report distributed under the terms of the Creative Commons Attribution License, which permits unrestricted use, distribution, and reproduction in any medium, provided the original work is properly cited.

\section{Eleanor Gaunt}

Department of Infection and Immunity, The Roslin Institute, The University of Edinburgh, Edinburgh, UK

\section{Synopsis:}

Nyaguthii and colleagues describe the screening of 483 individuals from 47 households for respiratory viruses over a 6 month period in the 2009-2010 respiratory syncytial virus (RSV) season. In this report, the detection data for human coronaviruses OC43, NL63 and 229E are described. There are some intriguing numbers on reinfection and duration of 'shedding' (as proxied using PCR positivity). The data are of interest because we have seen these types of studies in the developed world, but in this study, a household has, on average, over 10 individuals, and so these data provide a far more robust investigation of within household transmission. The data are thoroughly analysed, carefully interpreted, and the discussion is sensible and does not overinterpret.

\section{Major Comment:}

There raw data linked in the manuscript is restricted access for ethical reasons, so I cannot review it. Is it not possible to anonymise the data and share it that way? (I appreciate that this may not be possible given how detailed the data are).

\section{Minor Comments:}

1. Methods: Although the study design is previously published, a sentence on how the clinical data were collected would be appropriate.

2. Methods: Why is HCoV-HKU1 not screened for?

3. Methods: RT-PCR should read RT-qPCR.

4. Methods: hMPV should be reannotated HMPV in line with ICTV guidance. Similarly throughout the manuscript hCoV and HCoV are used interchangeably; this should be HCoV throughout. 
5. Methods: The paragraphs below the 'Statistical analysis' section are lacking headings.

6. Methods: Using PCR based detection as a proxy for shedding raises an eyebrow. As the approach can be expected to be consistent across the viruses, the relative measures of shedding are likely reasonable, but the raw numbers may not be. This is briefly commented on in the discussion but I feel that this could be elaborated.

7. Results: in baseline characteristics, for gender references 'male' is referred to when these were a minority in the study set. The majority population (female) should instead be referred to unless gender was unavailable/ not disclosed for some subjects.

8. Results: The sentence 'Symptomatic individuals contributed to 240 ...of samples that tested negative' is confusing to read and I am not really sure what this is saying - please rephrase for clarity.

9. Results: There are several places where 'any HCoV type' is referred to, but I am not sure whether this is referring to specifically mixed infections- in some cases, it seems to be. Can this be defined somewhere?

10. Figure 1: I cannot distinguish between open and closed dots, are they really different? (I am looking at a print out)

11. Results: For the duration of shedding, if I am interpreting Fig. 1 correctly, you have some examples where shedding occurs for over 3 months. That is worth a sentence or two! (Also in the discussion)

12. Results: Reinfection data describe occasions where individuals tested positive in sequential tests, but these were categorised as reinfection. On what basis was that judgement made? It seems counterintuitive.

13. Results: Reinfection data describe the frequencies of reinfection with each of the three HCoVs studied - do these frequencies differ from the overall frequencies?

14. Discussion: The abstract mentions SARS-CoV-2, but no parallels are made in the discussion either take this out of the abstract or make an interpretation in the discussion.

Is the work clearly and accurately presented and does it cite the current literature? Yes

Is the study design appropriate and is the work technically sound?

Yes

Are sufficient details of methods and analysis provided to allow replication by others? Partly

If applicable, is the statistical analysis and its interpretation appropriate? 
Yes

Are all the source data underlying the results available to ensure full reproducibility? Partly

Are the conclusions drawn adequately supported by the results?

Yes

Competing Interests: No competing interests were disclosed.

Reviewer Expertise: RNA virology

I confirm that I have read this submission and believe that I have an appropriate level of expertise to confirm that it is of an acceptable scientific standard. 